\title{
As patients get older, we should be aware of salt levels in factor products
}

\section{Sharon Alavian, Wendy Hutchinson}

Hypertension is a well-known risk factor for ischaemic heart disease and cerebrovascular events. Globally, there is a drive to try to reduce salt intake. In an older population, where hypertension is likely to have a high prevalence, are health care professionals aware of the sodium content in replacement factor?

Keywords: sodium, ageing, haemophilia, hypertension

In the UK, the introduction of replacement factor concentrates has had an enormous impact on the wellbeing and life expectancy of those with bleeding disorders. Prior to the introduction of adequate treatments, many people with haemophilia died before reaching adulthood [1]. With advances in treatment and care, children born with haemophilia in the United Kingdom (UK) today have a normal life expectancy [2]. As we now also have an everincreasing older population, it is now appropriate to consider the numerous health issues associated with this in relation to haemophilia. As studies have reported that people with haemophilia have an increased risk of hypertension, this is a particular area of interest $[3,4,5]$.

Hypertension is a well-known risk factor for ischaemic heart disease and cerebrovascular events. Strokes are known to be the second leading cause of death in the over60 age group [6]. Globally, strokes affect 15 million people per year; of these, 6 million people die and 5 million are left permanently neurologically impaired [6].

Blood pressure measurements should now be done routinely on all adult patients as part of their care when attending haemophilia clinics [4]. High blood pressure in adults is defined as a reading over $140 / 90 \mathrm{mmHg}$ (see Figure 1) [7]. Obesity, lack of exercise, smoking and alcohol intake can all contribute to a raised blood pressure. However, it is the intake of sodium in salt that is credited with being the major contributing factor in hypertension [8].

Salt is made up of $40 \%$ sodium and $60 \%$ chloride by weight. Sodium $(\mathrm{Na})$ is an electrolyte which helps to maintain blood

Sharon Alavian, Clinical Nurse Specialist Haemostasis, Imperial College Healthcare NHS Trust, London, UK

Email: Sharon.alavian@imperial.nhs.uk

Wendy Hutchinson, Clinical Nurse Specialist Haemostasis, Imperial College Healthcare NHS Trust, London, UK

Email: Wendy.hutchinson@imperial.nhs.uk

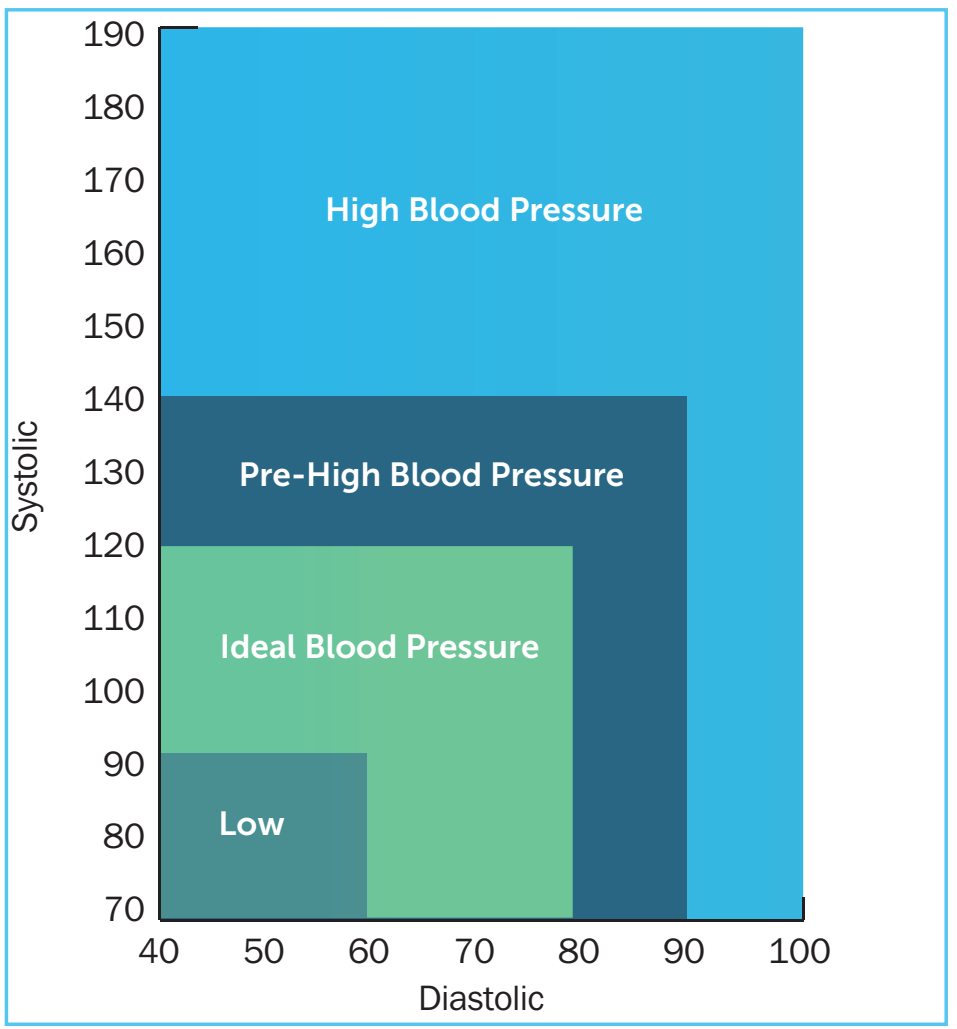

Figure 1: Classification of blood pressure for adults (from www.bloodpressureuk.org/BloodPressureandyou/ Thebasics/Bloodpressurechart)

pressure, regulate a normal fluid balance, and helps in the transmission of nerve impulses and muscle contractions. Sodium levels are regulated by the kidneys and adrenal glands, which control whether the body stores the sodium or excretes it into the urine [8]. Sodium is found naturally in most foods, and is often added to food products in the form of monosodium glutamate (MSG), sodium nitrate, sodium

Table 1: Recommended salt intake for children

\begin{tabular}{|c|c|}
\hline \multicolumn{1}{|c|}{ Age } & Maximum salt intake \\
\hline $0-6$ months & $<1 \mathrm{~g} /$ day \\
\hline $6-12$ months & $1 \mathrm{~g} /$ day \\
\hline $1-3$ years & $2 \mathrm{~g} /$ day \\
\hline $4-6$ years & $3 \mathrm{~g} /$ day \\
\hline $7-10$ years & $5 \mathrm{~g} /$ day \\
\hline 11 years and above & $6 \mathrm{~g} /$ day \\
\hline
\end{tabular}




\begin{tabular}{|c|c|}
\hline Name of factor & $\begin{array}{c}\text { Sodium level } \\
\text { Advate }\end{array}$ \\
\hline Alphanate & $230 \mathrm{mg}$ per $1,000 \mathrm{IU}$ vial \\
\hline Benefix & $<23 \mathrm{mg}$ per vial* \\
\hline DDAVP $(4 \mathrm{mcg} / \mathrm{ml})$ & $9 \mathrm{mg}$ per $\mathrm{ml}$ \\
\hline DDAVP nasal spray & $7.5 \mathrm{mg}$ per $\mathrm{ml}$ \\
\hline Fandhi & $<23 \mathrm{mg}$ per $1,000 \mathrm{IU}$ vial \\
\hline Feiba & 80mg per $500 \mathrm{IU}$ and $1,000 \mathrm{IU}$ vial \\
\hline Haemate P & $200 \mathrm{mg}$ per $2500 \mathrm{IU}$ vial \\
\hline Helixate Nexgen & $70 \mathrm{mg}$ per $1,000 \mathrm{IU}$ vial \\
\hline Kogenate & $23 \mathrm{mg}$ per $1,000 \mathrm{IU}$ vial \\
\hline Novo 7 & $23 \mathrm{mg}$ per $1,000 \mathrm{IU}$ vial \\
\hline Refacto AF & $5.84 \mathrm{mg}$ of sodium per $1.2 \mathrm{mg}$ Novo 7 \\
\hline Voncento & $29 \mathrm{mg}$ per vial* \\
\hline Wilate & $29.5 \mathrm{mg}$ per 1,000 iu/2400 IU vial \\
\hline
\end{tabular}

*Irrespective of factor level in vial

Table 2: Factor concentrates and their sodium levels based on information obtained from the Medical Information Departments of individual pharmaceutical companies producing factor products.

saccharin, sodium bicarbonate and sodium benzoate [9].

There is much debate about the recommended daily amount of salt that an adult should consume, the World Health Organisation (WHO) recommends $<2 \mathrm{~g} /$ day sodium (5g/day salt) [10]. To put this into perspective, 1 teaspoon of table salt contains $2.3 \mathrm{~g}$ of sodium. For healthy adults up to 50 years of age, the recommended salt intake is between $1.5 \mathrm{~g}-2.3 \mathrm{~g}$ sodium per day. For adults over 50 years of age, it drops to $1.3 \mathrm{~g}$ per day; and for the over-70s it is about $1.2 \mathrm{~g}$ a day [11]. Adults with high blood pressure should have no more than $1.5 \mathrm{~g}$ per day [12]. The UK Government has embarked upon extensive campaigns to alert the general public of the need to reduce their daily salt intake. In the UK, the average salt intake is approximately $8.6 \mathrm{~g}$ of salt daily. A reduction in salt intake is associated with lowering blood pressure within 4 weeks [13].

Thus, sodium, although essential for our health and well-being, can also have a detrimental effect on health if consumed excessively. A reduction in daily salt intake is recommended for the older population, and especially for people of South Asian or Black African ethnicity as these groups are recognised as having an increased sensitivity to salt [8]. It is estimated that by reducing global salt consumption to the recommended level, 2.5 million deaths could be prevented each year [8]. Reducing salt intake should therefore be taken seriously by everyone. The National Institute of Clinical Excellence (NICE) is currently aiming to reduce the maximum intake of salt in adults in the UK to $6 \mathrm{~g}$ per day by 2015, with further reductions to $3 g$ by 2025 [14]. The recommended salt intake for children varies according to age (Table 1).

Following the introduction of replacement clotting factors, the lives and life expectancy of people with bleeding disorders have improved considerably. It is therefore now appropriate to consider whether factor concentrates have

Table 3: Factor concentrates and their sodium levels per 3,000 IU of factor concentrate, based on information obtained from the Medical Information Departments of pharmaceutical companies producing factor products

\begin{tabular}{|c|c|c|c|}
\hline \multirow[t]{2}{*}{$\begin{array}{l}\text { Name of } \\
\text { factor }\end{array}$} & \multirow[t]{2}{*}{ Sodium level } & \multicolumn{2}{|c|}{$\begin{array}{c}\text { Sodium level on administration of } 3,000 \mathrm{IU} \text { factor concentrate according to } \\
\text { vial used }\end{array}$} \\
\hline & & Example & Total sodium \\
\hline Advate & 10mg per vial* & $\begin{array}{l}3 \times 1000 \mathrm{IU} \\
6 \times 500 \mathrm{IU}\end{array}$ & $\begin{array}{l}30 \mathrm{mg} \\
60 \mathrm{mg}\end{array}$ \\
\hline Alphanate & 230mg per 1,000 IU vial & $3 \times 1000 \mathrm{IU}$ & $690 \mathrm{mg}$ \\
\hline Benefix & $<23 m g$ per vial* & $3 \times 1000 \mathrm{IU}$ & $<69 \mathrm{mg}$ \\
\hline Fandhi & $<23 m g$ per 1000 IU vial & $3 \times 1000 \mathrm{IU}$ & $<69 \mathrm{mg}$ \\
\hline Feiba & $\begin{array}{l}80 \mathrm{mg} \text { per } 500 \mathrm{IU} \text { and } 1000 \mathrm{IU} \text { vial } \\
\text { 200mg per } 2500 \mathrm{IU} \text { vial }\end{array}$ & $\begin{array}{c}2500 \mathrm{IU}+500 \mathrm{IU} \\
3 \times 1000 \mathrm{IU} \\
6 \times 500 \mathrm{IU}\end{array}$ & $\begin{array}{l}280 \mathrm{mg} \\
240 \mathrm{mg} \\
480 \mathrm{mg}\end{array}$ \\
\hline Haemate $\mathrm{P}$ & 70mg per 1000 IU vial & $3 \times 1000 \mathrm{IU}$ & $210 \mathrm{mg}$ \\
\hline $\begin{array}{l}\text { Helixate } \\
\text { Nexgen }\end{array}$ & 23mg per 1000 IU viall & $3 \times 1000 \mathrm{IU}$ & $69 \mathrm{mg}$ \\
\hline Kogenate & 23mg per 1000 IU vial & $3 \times 1000 \mathrm{IU}$ & $69 \mathrm{mg}$ \\
\hline Refacto AF & 29mg per vial* & $\begin{array}{l}3 \times 1000 \mathrm{IU} \\
6 \times 500 \mathrm{IU}\end{array}$ & $\begin{array}{l}87 \mathrm{mg} \\
174 \mathrm{mg}\end{array}$ \\
\hline Voncento & 29.5mg per 1000 IU/2400 IU vial & $3 \times 1000 \mathrm{IU}$ & $88.5 \mathrm{mg}$ \\
\hline Wilate & 117.3mg per 1000 IU vial & $3 \times 1000 \mathrm{IU}$ & $35.19 \mathrm{mg}$ \\
\hline
\end{tabular}

*Irrespective of factor level in vial 
undesirable effects which were not previously relevant.

As can be seen in Table 2, the levels of sodium in different factor concentrates can vary considerably. For those patients who have a history of hypertension, it may be pertinent to consider this information when prescribing factor products. There are industry guidelines regarding the packaging and labeling of medication to ensure clarity and to enable medicines to be used safely [15]. The British Heart Foundation states that: "All medicines that contain at least $1 \mathrm{mmol}$ (or $23 \mathrm{mg}$ ) of sodium - a component of salt in each dose are required to declare on their labelling that the product contains sodium" [16]. However, there seems to be no consensus on how this information should be represented, potentially leading to difficulties in how it is interpreted. For instance, different factor products display sodium levels in mmols, mgs, $\mathrm{mEq}$ or as a percentage. This lack of consistency could increase confusion regarding sodium content and makes the direct comparison of factor products difficult in this respect. The data in Table 3 makes it clear that factor replacement products do contain sodium, some in significant levels. As such, haemophilia practitioners should have increased awareness of this issue.

Some vials of factor concentrates have the same quantity of sodium, irrespective of the amount of factor concentrate they contain, e.g. 500 IU or 1,000 IU. The total amount of sodium administered can therefore vary significantly, depending on the size of the vials used to make up the required amount of factor concentrate (see Table 3). As noted above, it is recommended that the maximum daily intake of sodium for healthy adults is between $1.5 \mathrm{~g}-2.3 \mathrm{~g}$, and less than $1.5 \mathrm{~g}$ for those with hypertension. Whilst some products contain as little as $30 \mathrm{mg}$ of sodium per 3,000 IU of factor concentrate, others contain $690 \mathrm{mg}$ of sodium per 3,000 IU of factor concentrate. Therefore, depending on the choice of factor concentrate prescribed, the vial sizes used and the frequency of administrating the dosage to achieve haemostasis, this could significantly contribute to the overall daily sodium intake. This may be particularly significant for children undergoing immune tolerance induction therapy due to the frequency of administration of factor concentrates. There could also be a cumulative effect, contributing to the increased incidence of hypertension in adults.

Other factors, such as obesity, lack of exercise, smoking and alcohol intake, can contribute to hypertension. Foods high in potassium may help to reduce the adverse effects of sodium on blood pressure [17]. Health professionals should be proactive in promoting a healthy diet, rich in fruit and vegetables and low in saturated fats, and in encouraging people to be physically active and stop smoking, as these will also help to reduce blood pressure [18]. Being aware of the sodium levels in replacement products may also help health professionals to make informed choices for individuals who need to reduce their sodium intake.

Blood pressure is routinely monitored when patients attend their haemophilia centre for review. Readings should be communicated to general practitioners (GPs) as they are responsible for management of blood pressure. Regular liaison between haemophilia centres and the patient's GP will enable provision of the best care for patients. In addition, studies are needed to clarify the prevalence of hypertension in the UK haemophilia population and to establish whether lifetime exposure to replacement clotting factors results in an increased risk associated for hypertension.

\section{Disclaimers}

The authors have advised that there are no interests that might be perceived as posing a conflict or bias. This article has not been influenced by any drug company to promote any particular product, and is not intended to do so.

This is an Open Access article distributed under the terms of the Creative Commons Attribution License (http://creativecommons.org/licenses/ by/2.0), which permits unrestricted use, distribution, and reproduction in any medium, provided the original work is properly cited.

\section{References}

1. Makris M. Prophylaxis in haemophilia should be life-long. Blood Transfusion 2012; 10(2): 165-58.

2. World Federation of Haemophilia. About bleeding disorders: frequently asked questions. 2012. Available from

http://www.wfh.org/en/page.aspx?pid=637\#Life_expectancy (accessed July 2015).

3. Blood Pressure Association. Blood pressure chart. 2008. Available from http://www.bloodpressureuk.org/BloodPressureandyou/Thebasics/ Bloodpressurechart (accessed 14 September 2015).

4. Fransen van de Putte DE, Fischer K, Makris M et al. Increased prevalence of hypertension in haemophilia patients. Thromb Haemostasis 2012; 108(4): 750-55

5. Von Drygalski A, Kolaitis NA, Bettencourt R et al. Prevalence and risk factors for hypertension in hemophilia. American Heart Association 2013; 62: 209-15

6. World Heart Foundation. Stroke. 2015. Available from http://www.worldheart-federation.org/cardiovascular-health/stroke/ (accessed 1 August 2015).

7. US Department of Health and Human Services, National Institutes of Health, National Heart, Lung and Blood Institute. Classification of blood pressure. In: The seventh report of the Joint National Committee on Prevention, Detection, Evaluation and Treatment of High Blood Pressure. 2004. Available from http://www.nhlbi.nih.gov/files/docs/guidelines/ jnc7full.pdf (accessed 25 September 2015).

8. World Action on Salt and Health. Salt and blood pressure. 2010. Available from http://www.worldactiononsalt.com/salthealth/factsheets/ bloodpressure/index.html (accessed 1 August 2015)

9. Sheehen K. Different names for sodium in food. Available from http:// healthyeating.sfgate.com/different-names-sodium-food-2141.html (accessed 1 August 2015)

10. World Health Organization. Guideline: Sodium intake for adults and children. 2012. Available from http://www.who.int/nutrition/publications/ guidelines/sodium_intake_printversion.pdf (accessed 1 August 2015).

11. Canadian Liver Foundation. Sodium guidelines. 2015. Available from http://www.liver.ca/liver-disease/having-liver-disease/healthy-livingguidelines/sodium-guidelines.aspx (accessed 8 August 2015).

12. The Medical Letter. Salt restriction: from The Medical Letter on Drugs and Therapeutics. J Am Med Assoc 2014; 33(21): 2229. Available from http://jamanetwork.com/article.aspx?articleid=1877204 (accessed 11 August 2015)

13. He FJ, Jiafu L, MacGregor GA. Effect of longer term modest salt reduction on blood pressure. Cochrane systematic review and meta-analysis of randomised trials. Br Med J 2003; 346: 1325. Available from http://www. bmj.com/content/346/bmj.f1325 (accessed 12 August 2015).

14. National Institute for Health and Care Excellence. Prevention of cardiovascular disease. NICE public health guidance 25. 2010. Available from http://www.nice.org.uk/guidance/ph25/resources/guidanceprevention-of-cardiovascular-disease-pdf (accessed 11 August 2015).

15. Medicines and Healthcare Products Regulatory Agency (MHRA). Best 
practice guidelines on the labelling and packaging of medicines. 2012. Available from https://www.gov.uk/government/uploads/system/uploads/ attachment_data/file/328404/Best_practice_guidance_on_the_labelling_ and_packaging_of_medicines.pdf (accessed 13 August 2015).

16. British Heart Foundation. The truth about salt and medicines. 2013. Available from https://www.bhf.org.uk/heart-matters-magazine/news/ behind-the-headlines/salt-in-medicines (accessed 11 August 2015).

17. Blood Pressure UK. Why potassium helps to lower blood pressure. 2008. Available from http://www.bloodpressureuk.org/microsites/salt/Home/ Whypotassiumhelps (accessed 12 August 2015).

18. Scientific Advisory Committee on Nutrition. Salt and Health. 2003. Available from https://www.gov.uk/government/uploads/system/ uploads/attachment_data/file/338782/SACN_Salt_and_Health_report.pdf (accessed 11 August 2015).

\section{The Journal of} Haemophilia

\section{Practice}

An open-access journal for sharing experience in

the care of people with bleeding disorders

\section{www.haemjournal.com}

